\title{
Inquiring into the Coloniality of Knowledge, Power, and Being in EFL Textbooks
}

\author{
Indagar la colonialidad del saber, del ser y del poder \\ en libros de texto de inglés
}

\author{
Astrid Núñez Pardo ${ }^{1}$
}

\begin{abstract}
This article inquires into the coloniality present in EFL textbooks, which continue being used as the core resource for language learning and teaching in Colombia. However, its instrumentalization, imperialism, and exploitation as an instrument of subalternation suggest that EFL textbooks produced by foreign and local publishing houses in the Colombian context are colonised in three interrelated dimensions: knowledge, power, and being. Therefore, this research proposal aims at unveiling the ontological, epistemological, and power criteria rooted in critical interculturality as a decolonial alternative, and inspired by the decolonial turn, to orient the development of other contextualised materials from the voices of Colombian teachers, authors and experts.
\end{abstract}

Keywords: coloniality of knowledge, power and being, critical interculturality, EFL textbook

\section{Resumen}

Este artículo problematiza la colonialidad presente en los textos de inglés porque continúan empleándose como recurso principal en la enseñanza y aprendizaje de este idioma. No obstante, su instrumentalización, imperialismo y explotación como instrumentos de subalternización sugiere que los textos producidos por editoriales locales y extranjeras, en el Contexto Colombiano, son coloniales en las dimensiones del saber, del poder y del ser. Esta propuesta busca develar los criterios ontológicos,

Astrid Núñez Pardo, a professor in the Master's Programme in Education at Universidad Externado de Colombia, holds a PhD in Education Sciences from Universidad Pedagógica y Tecnológica de Colombia (UPTC), an MA in Education from Universidad Externado de Colombia, and a Diploma in Linguistic Studies from University of Essex, UK.

astrid.nunez@uexternado.edu.co

ORCID: https://orcid.org/0000-0001-6176-4520

Received: April 21st, 2020. Accepted: August 4th, 2020.

This article is licensed under a Creative Commons Attribution-Non-Commercial-No-Derivatives 4.0 International License. License Deed can be consulted at https://creativecommons.org/licenses/by-ncnd/4.0. 
epistemológicos y del poder, cimentados en la interculturalidad crítica e inspirados en el giro decolonial, para orientar el desarrollo de materiales-otros contextualizados, desde las voces de los maestros, los autores y los expertos colombianos.

Palabras clave: el libro de texto de inglés, la colonialidad del saber, el poder y el ser, interculturalidad crítica

\section{Introduction}

The interest in this theme arises from my reflection as a teacher educator of in-service English language teachers in the fields of research and materials development, and as an author of textbooks, workbooks and teachers' guides for EFL teaching. Other reasons include the need for a critical interculturality-oriented curriculum and the development of intercultural competences as central to teaching EFL and ESL. Lastly, the issue is that despite the variety of EFL teaching resources, English language textbooks remain the 'main resource of the process of teaching and learning English' (Castañeda \& Rico, 2015; Davcheva \& Sercu, 2005; Núñez-Pardo, 2018b; Tomlinson 1988; Valencia, 2006). Thus, it is vital to rethink and redefine EFL materials as sociocultural, pedagogical, didactic, and cognitive mediations that facilitate linguistic and cultural interactions, and that are used in Colombia for bilingual (English) education at all levels. These mediations fulfil their sociocultural, political, academic, and aesthetic functions for teaching solidary, responsible, critical, and autonomous citizens who are conscious of their own culture, respectful of those of others, and aware of differences.

Since the EFL "textbook misrepresents the plurality of the local and foreign cultures" (Núñez-Pardo, 2018b, p. 1), they do not "respond to the local needs, interests, and life experiences of the learners in their own context" (Núñez-Pardo, 2020a, p. 23), and they decide whose culture, knowledge, and history become legitimised. This proposal aims at unveiling the ontological, epistemological, and power criteria, rooted in critical interculturality as a decolonial alternative, to orient the development of other contextualised materials, created by other teachers, and for other students within their own particular context in the periphery countries. It seeks to overcome its decontextualisation and long dependence on foreign ideologies, and to offer spaces for the local, stemming from Colombian teachers', experts' and authors' voices. Critical interculturality, inspired in the decolonial turn, seeks to contribute to the negotiation of socio-cultural diversity and to the conciliation of the difference between what is local and what is foreign, or different (Walsh, 2005a). Hence, EFL textbook content (terminology, themes, written and oral texts, iconography, and learning activities) continue to legitimise, naturalise, and perpetuate predetermined knowledge, ways of being, and by exerting power to conceal, distort or misrepresent the multiplicity of sociocultural and political local realities. This proposal problematises the uncritical 
development of EFL textbooks as they are decontextualised in terms of knowledge, being, and power.

\section{The Problem}

This inquiry identifies the coloniality of EFL textbooks in three interrelated dimensions: its instrumentalisation shows that it is colonial in the dimension of knowledge; its imperialism manifests that it is colonial in the dimension of power; and its exploitation as a subalternation instrument indicates that it is colonial in the dimension of being. According to Quijano (2014), in Latin America, European colonisation led to a Eurocentric vision of knowledge and to relationships of superiority and inferiority between the dominant and the dominated ones. As Fanon (1963) explains, colonialism oppressed, distorted, disfigured, and annihilated people to promote cultural alienation and to convince them that its purpose was to preserve them from darkness, barbarism, and from their ontological disgrace. Then, from an epistemological stance, the boundaries of natural sciences are questioned to respond to the broad range of social purposes (De Sousa, 2010a; Gadamer, 2002; Habermas, 1965; Mardones, 2003; Torres, 2010; Valtierra; 2013; Vasco, 1990; Zuleta, 1990). This is so, since the sense of lifeworld (Husserl, 2008) cannot be brought down to universal hegemony assumptions, objectivity, determinism, monism, and neutrality of scientific activity, as nothing in life is neutral or completely objective. It is from daily life that ontologies, epistemologies, and critical autonomies are envisioned.

Power schemes emerged from European colonialism in the social and historic context of the discovery and conquest of America (Quijano \& Wallerstein, 1992). They are produced and perpetuated in socio-historical environments, naturalising racial, social, and cultural hierarchies, reproducing control relationships of territories (Howatt \& Widdowson, 2004; Quijano, 2014; Restrepo \& Rojas, 2010), and maintaining the structure of centre-periphery relations on a world-wide scale in a global coloniality (Castro-Gómez \& Grosfoguel, 2007) with epistemic structures (De Sousa, 2006, 2010a; Lander, 2000a). These power patterns affect knowledge production and guarantee the exploitation of some human beings on a global scale (Maldonado-Torres, 2008; Mignolo, 2007; Quijano, 2014; Quijano \& Wallerstein, 1992). This, in turn, subalternates and obstructs the generation of local knowledge, experiences, and ways of life of the subjugated and exploited individuals, spreading itself beyond the colonial regimes. As expressed by Freire (2004), the First World has always been an exemplar model of all types of scandals, harm, and exploitation.

This type of coloniality has been perpetuated until our times and it is perceived in the sociocultural expressions of the modern experience of individuals, to the extent that everything that originates from Western countries is more valued. This is the case of EFL textbooks produced by foreign publishing companies and their branches in the periphery ${ }^{2}$. 


\section{Coloniality of Knowledge}

English textbooks have been instrumentalised by focusing on the mechanical use of grammar structures (Kramsch, 1993; Masuhara, Hann, Yi \& Tomlinson, 2008; Núñez-Pardo, 2018a, 2018b; Núñez, Téllez \& Castellanos, 2013; Pennycook, 1994; Phillipson, 2012; Prabhu, 1987; Pulverness, 2013; Rico, 2012; Tomlinson, 2013). They have also been developed under foreign methodologies that disregard the particularities of local contexts where English is learnt and taught (Allwright, 1981; Canagarajah, 2002, 2005, 2010; Giroux, 1988; Giroux \& Simon, 1988; Kumaravadivelu, 2014; Núñez-Pardo, 2018a, 2020; Prabhu, 1987, 1990; Waters, 2009). Thence, EFL textbooks have turned the teacher's role into a routine and repetitive one (Fernández-Reiris, 2006; Kincheloe \& McLaren, 2005; Littlejohn, 2012; Prabhu, 1987), which results in a conformist way of action (De Sousa, 2010a). In light of this, EFL textbooks have been marketed and imposed as hegemonically naturalised instruments of English language teaching par excellence, by foreign and local editing companies, as well as by education and ministerial institutions. Moreover, EFL textbooks mainly promote cultures that are alien to local ones, with an emphasis on superfluous, marketable, monolithic, and static aspects of the predominant cultures (Prodromou, 1988; Núñez-Pardo, 2018a, 2020b), or as Kramsch (1998) identifies them, by using the 4 fs: festivals, food, folklore, and statistical facts. Similarly, Gómez (2015) and Bandura and Sercu (2005) name these superfluous aspects as superficial culture whereas Waters (2009) refers to it as cultural bias, which constrains the generation of knowledge and 'comprehension of alternative counter-culture' (Quijano, 1980). Thus, EFL textbooks maintain "their cultural supremacy [and a] homogenous vision of universal culture at the expense of marginalising existing cultural diversity" (Núñez-Pardo \& Téllez-Téllez, 2020, pp. 30-31). This cultural incompleteness implies that the content and iconography of EFL textbooks mostly represent North American and British cultures, which is an instrument of cultural hegemony (De Sousa, 2018) that neither aids the construction of intercultural competence (Rico, 2012; Bandura \& Sercu, 2005), nor the development of critical conscience (Freire, 1971; Pennycook, 1994, 1998), or critical interculturality (Walsh, 2009). This cultural universalism portrayed in EFL textbooks advocates the idea of a unique predominant culture. It denies the cultural differences of the universe and, together with an organized predetermined knowledge system, harms the socio-political purpose of EFL materials as sociocultural mediations.

EFL textbooks are decontextualized since they "contain characteristics, values, attitudes and stereotyped communication styles from dominant cultures, with no representative anchor or context to be validated, which has not allowed learners to make it relevant to their own cultural experiences" (Núñez-Pardo, 2018a, p. 241). Also, they have become a dependence, submission, and subordination instrument since those locally produced are considered of poor quality. This is what González $(2012,2010)$ identifies as 'academic colonialism' in which foreign production is perceived as being better - due to their learning methods and 
strategies - than those that emerge from local experiences. Critical authors have referred to this phenomenon in a similar way. For example, 'intellectual colonialism' (Fals Borda, 1970); 'European colonialism, epistimicide, or cognitive colonialism’ (De Souza, (2010a, 2018); 'colonisation of knowledge' or 'eradication or imposed civilisation' (Lander, 2000a). What this epistemic colonialism intends to do is to transform into universal something that is universal for some. Indeed, Colombian unique historical, geographical, social, cultural, economic and aesthetic wealth becomes invisible in EFL textbooks. Instead, foreign ways of being, knowing and exerting autonomy are privileged and represented, which end up being imposed and disseminated in a seamless way through contents and methodologies originating from a culture that is not Colombian. In view of that, Núñez-Pardo (2020a) suggests:

By decen[tring] both the EFL textbook and the underlying methodologies, these resources are more likely to meet students' realities and thus, help them to make sense of learning a foreign language, to provide them the opportunity to reflect on their lived experiences within their own communities, and to propose alternative solutions to existing problems. (p. 15)

\section{Coloniality of Power}

EFL textbooks are associated with the economic, political, and commercial interests of the publishing industry (Álvarez, 2008; Apple, 1992; Canagarajah 2002; Cárdenas, González \& Álvarez, 2010; Giroux, 2001; González, 2010, 2012; Gray, 2013; Kumaravadivelu, 2014; Littlejohn, 2012; Núñez-Pardo, 2018a, 2020a, 2020b; Núñez-Pardo- \& Téllez-Téllez, 2018, 2020; Núñez et al., 2013; Pennycook, 1998; Phillipson, 2012; Rico, 2012; Usma, 2009). This imposes upon users the type of English that is taught, the type of content to be explored, the type of methodologies to be used, and even the type of learning activities and strategies to be proposed.

The previous condition homogenises and naturalises EFL teaching and learning processes in favour of the reductionist principle, 'one-size fits all', coined by Allwright (1981). EFL textbooks legitimise the interest of the prevailing social order (Giroux, 1997) and serve elitist interests permeated by colonialism, neoliberalism, and discriminatory discourses (Gray, 2013). Hence, content of EFL textbooks reproduce ways of being, knowing, and exercising independence that silence subjects that do not belong to the predominant Anglo-Saxon countries. According to Kincheloe (2008), this takes place in a world that is immersed in power dynamics that naturalises the predominant ways of continuous exclusion. Similarly, Kumaravadivelu $(2001,2014)$ claims that the methodologies that underlie EFL textbooks neglect the post-method condition. First, they disregard the parameter of particularity that entails comprehension of the sociocultural context (Sapir, 1949; Whorf, 1956). Second, they disdain the parameter of practicality that implies the self-contextualisation and selfconstruction of pedagogical local knowledge (Canagarajah, 2002; Giroux, 1988; González, 
2009; Kincheloe \& McLaren, 2005; Kumaravadivelu, 2003; Usma, 2009, Walsh, 2005b) from the theorisation of practices and the practice of theorization. Third, they ignore the parameter of possibility that involves critical socio-political awareness for the formation of identity and for social transformation (Freire, 1998, 2004; Kumaravadivelu, 2003); all being inherent in language teaching pedagogy. This standardisation of contents, methods, ideologies and privilege of English variety assumes uniformity in EFL teaching and learning processes. Hence, sameness leads to the naturalisation and perpetuation of ways of being, understanding, learning, interacting, and coexisting autonomously that marginalise and exclude subjects that originate from periphery countries (Asian, African, and Latin American).

It is necessary to resist hegemonic predetermined and decontextualized knowledge originating from Western countries and from the centre with the view of generating localised knowledge and teaching practices. Resisting the tradition of received knowledge with a critical understanding (Pennycook, 1998) is needed since language use implies "a position within the social order, a cultural politics, (and a) struggle over different representations of the self and other" (Pennycook, 1994, p. 34). For this reason, decolonised local practices and ideologies should constitute the basis for materials development, implementation and innovation. Considering that one's own cultural plurality conditions the development of knowledge in varied configurations (García, 2004) and that the teaching textbooks need to be questioned, deconstructed, and rethought (Edge \& Wharton, 1998, Núñez-Pardo, 2020b), we need to reduce dependence on Eurocentrism as the unique source of knowledge ${ }^{3}$ (Walsh, 2009) and achieve validation of locally-built materials and methodologies for EFL teaching. It means, discerning the criteria for other contextualised and decolonised materials, as "mediations in sociocultural interactions among learners from diverse cultural worlds" (Núñez-Pardo, 2020a, p. 18), in which differences and sociocultural diversity coexist, at the same level of importance and validity.

The enforcement of linguistic policies in Colombia have also been exposed to a permeation of hegemony of power, since the teacher becomes a technician, reproducer and preserver of foreign methodologies and contents, whose performance is evaluated according to the achievement of said parameters. In Giroux' (1998) insight, it is necessary to examine the ideological forces and materials that have contributed to the proletarisation of the teacher's role. This tendency brings teachers down to the level of a technician, who fulfils functions of management, and complies with curriculum programs instead of developing or critically assimilating the curriculums to adjust to specific pedagogical concerns. Diminishing the intellectual, pedagogical, and transformative role of teachers dehumanises them, limits their agency in making contextualised curriculum and materials decisions, and "perpetuates hegemonic language teaching and learning discourses" (Lucero-Babativa, 2020, p. 144).

If teachers wait for the MEN to make curricular, methodological and materials decisions, subordination is promoted on this imposition of predetermined knowledge. It 
paves the way for the resulting reproduction, dissemination, perpetuation, and naturalisation of decontextualized knowledge. One clear example of this situation is the existing alliance between the MEN and the British Council for the inclusion of a Suggested Curriculum (2016) in state-funded education institutions. Indeed, it is not a suggested curriculum but rather an imposed one, since the MEN is constantly sending managers to 'train' teachers on what should be taught and how it should be taught. It is evident that public bilingual education policies do not consider the particularities of education institutions, since it is through a 'suggestions' guise that they impose a series of predetermined contents and centre methodologies to support the bilingual programme Colombia Very Well (2014). In view of that, Moreno and Pájaro (2018) recommend 'indisciplining' the EFL syllabus to support bilingual educational achievements.

\section{Coloniality of Being}

It is rooted on the binaries reason - no-reason, humanisation - dehumanisation in which the English language teacher is not considered a member of the centre community (AngloSaxon countries) (Kachru, 1992), but of the subaltern one (Asia, Africa, Latin America), without the capacity to produce knowledge and instead to consume it. This is related to the dichotomies of native-speakers - non-native speakers (Graddol, 1999; Kumaravadivelu, 2012; Pennycook, 1998), the prevalence of hegemonic ideology of the native speaker (Faez, 2011; Fairclough, 1989; Kachru, 1992; Kubota \& Lin, 2006; Viáfara, 2016), and the binary hegemonic community - peripheric community (Dussel, 2007). Then, teachers and students should make critical sense of such domination dynamics that shape identities, knowledge, and self-directed actions.

If the subaltern community of non-native speakers wants to unsettle and disarticulate hegemonic power structures, it should resort to the 'decolonial option' (Mignolo, 2010), a category originally developed under the name 'decolonial turn' by the Puerto Rican philosopher Nelson Maldonado-Torres (2006). This decolonial alternative requires not only intellectual work, but also social action with coordinated and agreed collective results to resist the unilateral hegemonic power. Kumaravadivelu (2014, 2012) exhorts the subaltern intellectual teacher to provoke an epistemic rupture in the English language teaching field; he also proposes Mignolo's 'epistemic decolonisation' (2010). Similarly, Foucault (1972) recognises the existence of multiple epistemes within a specific discourse, since according to Kumaravadivelu (2014), the epistemic rupture is not exerted in a universal way. On the contrary, the subaltern subjects ought to use this epistemic discourse to make sense of and to legitimate their practices, as suggested by Fanon's (1963) decolonial discourse. The author claims that in times of struggle colonised intellectuals feel the need for expressing their nation being the speaker of a new reality in action. Thence, it is through the stimulation of 
collective and coordinated creative capacity of local subjects, who know the local conditions, that action is impelled to produce valid knowledge in pedagogical contexts.

As education for transformation and emancipation raises serious challenges, it deserves teachers' and students' concern and endeavours. Resistance to hegemonically imposed centre-based methods may be exerted by proposing other context sensitive methodologies that underpin other contextualised materials that foster both students' high-order thinking skills, critical socio-political awareness, and teachers' generation of "valid local knowledge, aligned with local needs and to the historical moment” (Núñez-Pardo, 2020b, p. 215). In this regard, Núñez \& Téllez (2018) claim that "by resisting the use of decontextualized and standardized materials, teachers become producers, not consumers, of context-bound teaching resources” (p. 83). Developing other contextualised materials informed by locally generated methodologies and learning strategies points to a decolonialised pedagogical practice that cultivates teachers' and students' critical socio-political awareness, going beyond 'abysmal thinking'4 or 'modern occidental thinking' (De Sousa, 2014). Conducting research that stems from the local demands generates genuine knowledge with a view to disrupting exclusive and absolute dependence from Eurocentric visions and cultural universalism.

It is the duty of teachers and students to enquire into and develop materials, learning strategies, and methodologies that emerge from their particular settings, including contents that account for their voices, life experiences, and community problems. This action of generating localised materials and methodologies acknowledges teachers as historical thinkers and transformers of the world (Freire, 1998), and subjects of knowledge (Foucault, 1980; Quiceno, 1988) since they possess not only 'content, pedagogical, curricular, learners, and educational purposes' knowledge (Shulman, 1987), but also “empirical, experiential, normative, critical, ontological, and reflective-synthetic domains” (Kincheloe, 2004, p. 51). In the Colombian context, Castañeda-Londoño (2018) argues both a traditional and universal as opposed to a critical and emancipatory teachers' knowledge base. Teachers are also regarded as "agents of permanent change" (Núñez \& Téllez, 2009, p. 184), "subaltern intellectuals" (Kumaravadivelu, 2014, p. 76), and public and transformative intellectuals (Giroux, 1988) within their communities. In essence, teachers' cognitive and critical knowledges enable them to express critical dissent and proposals regarding curricular, materials, and teachingpractices decisions.

This proposal problematises decontextualised EFL textbooks produced by foreign and local editing companies. Their contents, cultural representations, iconography and learning activities, as well are their methodologies do not comprise the changing complexity of historic, sociocultural, political, economic, education, and aesthetic experiences of local contexts and communities in which they are used. Power structures, originating from colonialism, affected sociability, public space, private space, culture, ways of thinking and subjectivities (De Sousa, 2010) that are maintained through capitalist globalisation in the periphery, and transcend 
racial and social status, reproducing epistemic and territorial dominions. Such structures exploit individuals on global scales, subordinate and obstruct knowledge emanating from the living experiences of the other submissive and exploited (Quijano, 2014) which, according to Dussel (2007), aims at homogenising humankind under criteria and values derived from a single English-speaking culture.

The previous condition implies that the anti-capitalist struggle in tandem with the anti-colonialist fight advocates for social class and ethnic equality, in which difference is appreciated and respected, and equality is sensitive to sociocultural diversity from across the world. However, global capitalism, represented through the 'cosmopolitan' or 'global' EFL textbook, idealises and naturalises consumerism practices including international trips, entertainment, and free time activities that impose the idea to irrationally spend money on gross luxuries (e.g. visiting exotic international landmarks and spatial touristic places). While teachers turn into naive consumers instead of critical producers of knowledge, students become dependent users, who can memorise and mechanically learn grammar structures, and who neither develop their communicative competence (Bandura \& Sercu, 2005; Gómez, 2015), nor their intercultural communicative competence (Rico, 2012).

Constraining the production of culturally, methodologically and epistemologically localised EFL materials maintains the asymmetry in sociocultural, economic, political, and academic relationships world-wide. Other contextualised materials reject the idea that there is a common homogenised culture. Also, they stimulate the inclusion, tackling and discussion of deep culture aspects as opposed to the exacerbated superficial culture. According to Byram (1997), Kramsch (1998), Moran (2001), and Núñez-Pardo (2020b), superficial culture supports, exaggerates or poorly represents culture through racist, sexist, classist, hetero sexist, ageism, and ableism stereotypes, privileging dominant cultures to the detriment and marginalisation of local ones. Since individuals' life experiences form part of the essential and complex aspects of their cultural universe, other contextualised EFL materials, based on critical interculturality, may offer better possibilities for cultural revival and appropriacy, and for students' and teachers' construction of high order thinking skills, critical socio-political awareness, and critical intercultural communicative competences.

This research proposal aims at providing a set of criteria for the development of other contextualised EFL materials grounded on critical interculturality. A contribution is intended towards this political, social, epistemic, and ethical project, which is also aesthetic in relation to its construction (Walsh, 2009). Firstly, it is conceived by the individuals in diverse educational places, in which the difference between local and foreign is harmonised (Walsh, 2005). Moreover, omissions of inexistences, denials of knowledge, time, differences, and covered faces are questioned (Dussel, 1994), as well as the absent (e.g. missing) categories (De Souza, 2010a). Secondly, spaces are created for equality-in-difference, since we have the right to be equal when the difference makes us inferior, and to be different when equality 
puts our identity at risk (De Sousa, 2010b). Diversity requires us to decentre and to critically ponder our own experience to make possible the education of autonomous, conscious, informed, and solidary citizens. Diversity demands attaining structural changes in our society (Pérez-Gómez, 1998), which are not limited to recognition as they dismiss differences and inequalities regarding ways of being, knowing, learning, feeling, dreaming and coexisting in an autonomous way.

\section{Review of Related Studies}

Mainstream research on EFL textbooks demonstrates latent tensions, criticisms and tendencies in the national and international context, as I have already discussed elsewhere (See Núñez-Pardo, 2018a). The 50 related studies reviewed (see next lines) argue how the content of EFL textbooks operates and contributes to the naturalisation and perpetuation of ways of being, knowing, and exerting power; ways that hide, distort or misrepresent the multiplicity of sociocultural realities in local contexts.

Several categories were identified:

- Sexism and stereotypical representation of genders (Craeynest, 2015; Dabbagh, 2016; Datzman, 2013; Ghorbani, 2009; Hall, 2014; Hill, 1980; Lee, 2014; Ndura, 2010; Nofall \& Qawar, 2015; Pereira, 2013; Porreca, 1984; Syarifuddin, 2014).

- Discourses of otherness and Eurocentric knowledge represent, reproduce, and perpetuate geo-cultural, historical, sociological and ethnological stances about 'the other' (Guijarro, 2005) with a manifest ranking of cultures (Yasinne, 2012).

- Decontextualisation of knowledge and an uncritical approach as hegemony legitimise official knowledge (Aicega, 2007; Di Franco, Siderac, \& Di Franco, 2007).

- The cultural component in the texts, learning activities and iconography privilege the superficial, visible, aesthetic, and monolithic culture of Anglo-speaking countries (Ahmed \& Narcy-Combes, 2011; Aliakbari \& Jamalvandi, 2013; AL-Obaidi, 2015; Bahrami, 2015; Bonilla, 2008; Dehbozorgi, Amalsaleh \& Kafipour, 2014; Fuentes, 2011; Habib, 2014; Jahan, 2012; Kirkgöz \& Ağçam, 2011; Nguyen, 2015; Rimani \& Soleimani, 2012; Varón, 2009; Xiao, 2010).

- Intercultural competence and intercultural communicative competence are not developed through EFL textbooks (Jiang, 2010; Rico, 2012; Gómez, 2015; Ajideh \& Panahi, 2016).

- Literacy findings suggest that contextualised reading comprehension activities foment literacy whereas the instrumental comprehension activities do not promote abstraction, inference, or critical reading (Valencia, 2006; Anvedsen, 2012; Zhang, 2017). 
- Children are not represented as rights-holders but as passive subjects who are unaware of them (Herrera, 2012). In light of this, Núñez-Pardo (2018a) recommends teachers and students to recognise "the hidden messages in these materials... to identify their poorly constructed and represented lost voices, and to critically examine their life experiences and their relationship with others in their communities and the wider world". (p. 235)

Despite this range of studies, research particularly centred on the analysis of EFL textbooks from the critical interculturality perspective is incipient and continues to awaken tensions and debate. As the criteria of knowledge, power, and being founded on critical interculturality have not been established to orient the development of other contextualised and decolonised materials, this proposal disrupts the uncritical instrumental approach of developing commercial EFL textbooks. As Núñez-Pardo (2020a) claims, "contextualisation destabilises mainstream ways of developing standardized, homogenized, decontextualized and meaningless materials" (p. 19). Undeniably, these criteria advocate other contextualised materials informed by locally emerging content and methods that are sensitive to cultural diversity, without omissions, distortions, biases, favouring the development of politically and culturally-aware subjects in accordance with their ethnic origin, social status, gender, age, creed, identities, and capacities.

Critical content analysis is proposed for the written texts, the iconography, and the reading comprehension activities of the six most used EFL textbooks in the Colombian context, during 2004 and 2016. This period corresponds to the time when the MEN's education policy was formulated and reformulated, affecting the production of EFL textbooks. Nonetheless, local and foreign EFL textbooks are facing a crisis in developing individuals' intercultural communicative competence, as it was previously argued. Lastly, the absence of critical analysis of the reading texts, iconography and comprehension activities in EFL textbooks used in the Colombian education context makes this enquiry worthy. Therefore, a main research question and three subsidiary questions are posed, as shown in Table 1 below.

This research proposal does not seek to analyse critical interculturality in the six most used textbooks since it arises as a response to existing coloniality in EFL textbooks; it does not assume the creation of an education EFL programme as the study stems from my own trajectory as an educator of in-service EFL teachers; and it does not suggest the development of a textbook because it cannot be decolonised with the same colonising instrument. This study calls for students' and teachers' resistance to hegemony, a search for their critical sociopolitical awareness, a committed agency, and generation of local knowledge, so that subaltern communities are considered as the locus for other epistemologies. 


\section{Table 1. Research Questions and Sub-questions}

Title: Decolonising the EFL Textbook in the Colombian Context: A Venture from Critical Interculturality

Research question: What are the ontological, epistemological, and power criteria grounded on critical interculturality as a decolonial alternative that orient the development of the EFL textbook to overcome its decontextualisation, from the voices of Colombian teachers, authors and experts?

Research Objective: To unveil the ontological, epistemological, and power criteria, grounded on critical interculturality as a decolonial alternative, to orient the development of the EFL textbook with the aim of overcoming its decontextualisation from the perspectives of Colombian teachers, authors and experts.

\section{Subsidiary Questions}

Subsidiary question 1: What coloniality traces can be observed in the written passages, the iconography and the learning activities of the EFL textbooks, which have been most widely used in the Colombian context in the period from 2004 to 2016?

Subsidiary question 2: What possible transformations have taken place in the existing contents of the written passages, iconography and learning activities in the EFL textbooks that have been most widely utilised in the Colombian context in the period between 2004 and 2006 ?

Subsidiary question 3: What perceptions do Colombian teachers, authors and experts have regarding existing coloniality among the written passages, comprehension activities and iconography contained in the EFL textbooks that have been most widely used during the period between 2004 and 2016?

\section{Specific Objectives}

Specific Objective 1: To characterise the contents related to existing coloniality in the written passages, comprehension activities and iconography within the most widely used EFL textbooks in the Colombian context during the period between 2004 and 2016, to identify coloniality traces. Specific objective 2: To identify the discourses related to decoloniality that are evident in the written passages, comprehension activities and iconography contained in the most widely used EFL textbooks in the period between 2004 and 2015, to determine the aspects related to decoloniality. Specific Objective 3: To understand the perceptions of Colombian teachers, authors, and experts regarding any existing coloniality in the written passages, iconography and comprehension activities that are contained in the most widely used EFL textbooks in the Colombian context during the period between 2014 and 2016, to unveil their awareness of coloniality. 
Inquiring into the Coloniality of Knowledge, Power, and Being in EFL Textbooks

\section{References}

Ahmed, F., \& Narcy-Combes, M. F. (2011). An analysis of textbooks from a cultural point of view. TESOL Journal, 5, 21-37.

Aicega, D. (2007). Los libros de texto para la enseñanza de inglés: Una mirada crítica. Puertas Abiertas, 3(3), 99-102.

Ajideh, P., \& Panahi, M. (2016). An analysis of culture-related content in English textbooks for Iranian students entitled 'Prospect' and 'Vision' Series. International Journal of Language and Linguistics, 3(6), 87-93.

Aliakbari, M., \& Jamalvandi, B. (2013). Realization of culture in English textbooks in Chinese high school level. Journal of Pan-Pacific Association of Applied Linguistics, 16(2), 89-101.

Allwright, R. L. (1981). What do we want teaching materials for? ELT Journal, 36(1), 5-18.

AL-Obaidi, L. (2015). The cultural aspects in the English textbook "Iraq opportunities" for intermediate stages. (Unpublished Master's thesis). Middle East University.

Álvarez-Valencia, J. A. (2008). Educational commercialism: ¿Is it overtaking EFL in Colombia? ASOCOPI Newsletter, p. 7.

Anvedsen, E. J. (2012). Textbooks, tasks and reading literacy: A close look at the teacher's resources in secondary school (Master's thesis). Norwegian University of Science and Technology NTNU.

Apple, M. (1992). The text and cultural politics. Educational Researcher, 21(7), 4-19.

Bahrami, N. (2015). Evaluating the representation of cultural elements in an in-use EFL textbook. Advances in Language and Literary Studies, 6(3), 128-137.

Baiqiang, T. (2008). Identifying and combating sexism in EFL textbooks- with a case study into China. Independent Researcher, P R China.

Bandura, E., \& Sercu, L. (2005). Culture teaching practices. In L. Sercu (Comp). Foreign language teachers and intercultural competence (pp. 75-89). Multilingual Matters.

Bao, D. (2013). Developing materials for speaking skills. In B. Tomlinson (Ed.), Developing materials for language teacbing (pp. 407-428). Bloomsbury Publishing Plc.

Bonilla, X. (2008). Evaluating English textbooks: A cultural matter. HOW Journal, 15, 167-191.

Byram, M. (1997). Teaching and assessing intercultural communicative competence. Multilingual Matters.

Canagarajah, S. (2002). Globalization, methods, and practice in periphery classrooms. In D. Block \& D. Cameron (Eds.), Globalization and language teaching (pp. 134-450). Routledge.

Canagarajah, S. (2005). Reconstructing local knowledge, reconfiguring language studies. In S. Canagarajah, (Ed). Reclaiming the local in language policy and practice (pp. 3-24). Lawrence Erlbaum Associates.

Canagarajah, S. (2010). Internationalizing knowledge construction and dissemination. Comments from the previous editor of TESOL Quarterly. The Modern Language Journal, 661-664.

Cárdenas, M., González, A., \& Álvarez, A. (2010). El desarrollo profesional de los maestros de inglés en ejercicio: Algunas consideraciones conceptuales para Colombia. In Folios, 31, 49-68. 
Castañeda, H., \& Rico, C. (2015). Rasgos característicos de la enseñanz̧a en Colombia en el área de inglés como lengua extranjera. Análisis de las propuestas pedagógicas presentadas al Premio Compartir al Maestro. Fundación Compartir.

Castañeda-Londoño, A. (2018). Revisiting the issue of knowledge in English language teaching, a revision of literature. Gist, Education and Learning Resource Journal, 18, 220-245. https://latinjournal.org/index.php/gist/article/view/686

Castro-Gómez, S., \& Grosfoguel, R., (Eds.) (2007). El giro decolonial: reflexiones para una diversidad epistémica más allá del capitalismo global. Bogotá: Universidad Central, Instituto de Estudios Sociales Contemporáneos y Pontificia Universidad Javeriana, Instituto Pensar.

Craeynest, F. V. (2015). Gender representations in EFL textbooks: a quantitative and qualitative content analysis. (Unpublished Master's thesis). Ghent University, Flanders, Belgium.

Dabbagh, A. (2016). Gender representation under critical image analysis: The case of Iranian ELT textbooks. International Journal of English Language \& Translation Studies. 4(4), 39-52.

Datzman, B. (2013). Gender representation and EFL textbooks: A case study. Journal of the Faculty of Global Communication, 14, 1-13.

Davcheva, L., \& Sercu, L. (2005). Culture in foreign language teaching materials. In L. Sercu (Comp). Foreign language teachers and intercultural competence. An international investigation (pp. 76-90). Multilingual Matters Ltd.

De Sousa, B. (2014). Más allá del pensamiento abismal: De las líneas globales a una ecología de saberes. Epistemologias del Sur (Perspectivas), 21-66.

De Sousa, B. (2006). La sociología de las ausencias y la sociología de las emergencias: Para una ecología de saberes. In S. De Sousa, Renovar la teoría crítica y reinventar la emancipación social (pp.13-41). CLACSO.

De Sousa, B. (2010a). Para descolonizar Occidente. Más allá del pensamiento abismal. CLACSO, Prometeo Libros,

De Sousa, B. (2010b). Descolonizar el saber, reinventar el poder. Ediciones Trilce.

De Sousa, B. (2014). Más allá del pensamiento abismal: De las líneas globales a una ecología de saberes. Epistemologías del Sur (Perspectivas), 21-66.

De Sousa, B. (2018). Construyendo las epistemologías del sur: Para un pensamiento alternativo de alternativas (Vol. 2). CLACSO.

Dehbozorgi, M., Amalsaleh, E., \& Kafipour, R. (2014). Exploring cultural content of three prominent EFL textbooks in Iran (a case study of American English File, Top Notch and Four Corners). Acta Didactica Napocensia, 7(1) 69-81.

Di Franco, M. G., Siderac, S., \& Di Franco, N. (2007). Libros de texto: ¿'saberes universales o descontextualizados? Horizontes Educacionales, 12(1), 23-33.

Dussel, E. (1994). 1942 el encubrimiento del otro. Hacia el origen del 'mito de la modernidad'. Plural Editores, Facultad de Humanidades y Ciencias de la Educación de la UMSA. 
Dussel, E. (2000). Europa, modernidad y eurocentrismo. In E. Lander (Ed), La colonialidad del saber: eurocentrismo y ciencias sociales: Perspectivas latinoamericanas (pp. 41-53). Ediciones Faces / UCV.

Dussel, E. (2007). Materiales para una política de liberación. Plaza y Valdéz Editores.

Edge, J., \& Wharton, S. (1998). Autonomy and development: Living in the materials world. In B. Tomlinson (Ed.), Materials development in language teaching (pp. 295-310). Cambridge University Press.

Faez, F. (2011). Reconceptualizing the native/non-native speaker dichotomy. Journal of Language, Identity \& Education, 10(4), 231-249.

Fairclough, N. (1989). Language and Power. Longman.

Fals Borda, O. (1970). Ciencia propia y colonialismo intelectual. Editorial Nuestro Tiempo.

Fanon, F. (1963). Los condenados de la tierra. Fondo de Cultura Económica.

Fernández-Reiris, A. (2006). La importancia de ser llamado "ibro de texto". Hegemonía y control del currículo en el aula. Niño y Dávila.

Foucault, M. (1972). The archaeology of knowledge and the discourse on language. Pantheon Books.

Foucault, M. (1980). Power/Knowledge. Selected interviews and other writings, 1972 - 1977. (Colin Gordon, Leo Marshall, John Mepham y Kate Soper, trad.). In C. Gordon (Ed.). Pantheon Books. (Original work published in 1972, 1975, 1976, 1977).

Freire, P. (1971), Pedagogy of the oppressed, trans. Myra Bergman Ramos. Herder and Herder.

Freire, P. (1998). Pedagogía de la esperanza. Siglo XXI Editores.

Freire, P. (2004). Pedagogía de la autonomía. Paz e Terra S.A.

Fuentes, M. (2011). Conocimiento escolary libros de texto. Una perspectiva intercultural. (Unpublished doctorate thesis). Universidad Nacional de Educación a Distancia, Madrid, España.

Gadamer, H. G. (2002). Acotaciones Hermenéuticas. Trotta.

García, N. (2004). Diferentes, desiguales y desconectados mapas de la interculturalidad. Gedisa.

Ghorbani, L. (2009). An investigation of the manifestation of sexism in EFL/ESL textbooks. https:// eric.ed.gov/?id=ED505434

Giroux, H. (1988). Los profesores como intelectuales. Una pedagogía crítica del aprendizaje. Traducción de Isidro Arias. Hurope, S. L.

Giroux, H. (1997). Pedagogy and the politics of hope: Theory, culture and schooling. Westview Press.

Giroux, H. (2001). Public spaces, private lives: Beyond the culture of cynicism. Roman \& Littlefield.

Giroux, H., \& Simon, R. (1988). Schooling, popular culture, and a pedagogy of possibility. Journal of Education, 170(1), 9-26.

Gómez, L. F. (2015). The cultural content in EFL textbooks and what teachers need to do about it. Profile: Issues in Teachers' Professional Development, 17(2), 167-187. http://dx.doi.org/10.15446/ profile.v17n2.44272

González, A. (2009). On alternative and additional certifications in English language teaching: The case of Colombian EFL teachers' professional development. Íkala, Revista de Lenguaje y Cultura, 14(22), 183-209. 
González, A. (2010). English and English teaching in Colombia. Tensions and possibilities in the expanding circle. In A. Kirkpatrick (Ed.). The Routledge Handbook of World Englishes (pp. 332-352). Routledge.

González, A. (2012). On English language teaching and teacher education. Academic disagreements in a developing country. http://conference.pixel-online.net/edu_future2012/common/download/Paper_pdf/524-SE76-FP-Gonzalez-FOE2012.pdf

Graddol, D. (1999). The decline of the native speaker. AIL A Review 13, 57-68.

Gray, J. (2013). Critical perspectives on language teacbing materials. Palgrave Macmillan Publishers Limited.

Guijarro, J. R. (2005) La representación axiológica del género y la orientación sexual en libros de texto de inglés para Secundaria. Porta Linguarum (4), 151-166.

Habermas, J. (1965). Ciencia y técnica como ideología. Editorial Tecnos.

Habib, A. (2014). An analysis of cultural load in English textbooks taught in Khyber Pakhtunkhwa, Pakistan. NUML Journal of Critical Inquiry, 12(2), 72-88.

Hall, M. (2014). Gender representation in current EFL textbooks in Iranian secondary schools. Journal of Language Teaching and Research, 5(2), 253-261.

Herrera, D. M. (2012). Children as subjects with rights in EFL textbooks. Colombian Applied Linguistic Journal, 14(1), 45-59.

Hill, P. (1980). Women in the world of ELT textbooks. EFL Gazette, 18/19, June/July.

Holliday, A. (1994): Appropriate methodology and social context. Cambridge University Press.

Holliday, A. (2005): The struggle to teach English as an international language. Oxford University Press.

Howard, J., \& Major, J. (2005). Guidelines for designing effective English language teaching materials. In Proceedings of the 9th Conference of Pan-Pacific Association of Applied Linguistics 101. Seoul, South Korea.

Howatt, A. P. R., \& Widdowson, H. G. (2004). A history of English language teaching. Oxford University Press.

Husserl, E. (2008). La crisis de las ciencias europeas y la fenomenología trascendental. Traducción y Estudio preliminar Julia V. Iribarne. Prometeo Libros.

Jahan, A. (2012). Residual cultural imperialism in primary textbooks in Bangladesh: A critique of the English for today textbooks. English for today, 3, 73-94.

Jiang, B. (2010). The role of college English textbooks in the teaching of culture in China. (Unpublished Doctorate Thesis). University of York.

Kachru, B. (1992). The other tongue: English across cultures. University of Illinois Press.

Kincheloe, J. L. (2008). Knowledge and critical pedagogy. An introduction. Springer Science + Business Media B. V.

Kincheloe, J. L. (2004). The knowledges of teacher education: Developing a critical complex epistemology. Teacher Education Quarterly, 31(1), 49-66. 
Kincheloe, J. L., \& McLaren, P. (2005). Rethinking critical theory and qualitative research. In N. K. Denzin \& Y. S. Lincoln. (Eds.), The Sage handbook of qualitative research (pp. 303-342). Sage Publications.

Kirkgöz, Y., \& Agcam, R. (2011). Exploring culture in locally published English textbooks for primary education in Turkey. CEPS Journal, 1(1), 153-167.

Kramsch, C. (1993). Context and culture in language teaching. Oxford University Press.

Kramsch, C. (1998). Language and culture. Oxford University Press.

Kubota, R., \& Lin, A. (2006). Race and TESOL: Introduction to concepts and theories. TESOL Quarterly, 40(3), 471- 493.

Kumaravadivelu, B. (2014). The decolonial option in English teaching. Can the subaltern act? TESOL Quarterly, 14(1), 66-85.

Kumaravadivelu, B. (2001). Postmethod pedagogy. TESOL Quarterly, 35(4), 537-560.

Kumaravadivelu, B. (2003). Beyond methods: Macro strategies for language teaching. Yale University Press.

Kumaravadivelu, B. (2012) Individual identity, cultural globalization and teaching English as an international language: The case for an epistemic break. In L. Alsagoff, S. McKay, H. Gwangwei \& W. Renandya (Eds.). Principles and practice for teaching English as an International Language (pp. 9-27). Routledge.

Lander, E. (ed.) (2000). La colonialidad del saber: Eurocentrismo y ciencias sociales: perspectivas latinoamericanas. CLACSO.

Lee, J. F. (2014). A hidden curriculum in Japanese EFL textbooks: Gender representation. Linguistics and Education, 26, 39-53.

Liddicoat, A. J. (2011). Language teaching and learning from an intercultural perspective. In E. Hinkel. Handbook of research in second language teaching and learning (pp. 837-855). Routledge.

Littlejohn, A. (2012). Language teaching materials and the (very) big picture. Electronic Journal of Foreign Language Teaching. 9(1), 283-297.

Loewenberg Ball, D., \& Feiman-Nemser, S. (1988). Using textbooks and teacher's guides. Curriculum Inquiry, 18(4), 401-23.

Lucero-Babativa, E. (2020). Bringing interactional identities into the study of classroom interaction in ELT education. Gist, Education and Learning Resource Journal, 135-153. https://doi. org/10.26817/16925777.714

Maldonado-Torres, N. (2006). Against War. Duke University Press.

Maldonado-Torres, N. (2008). On the coloniality of being. Contributions to the development of a concept. Cultural Studies, 21(2-3), 240-270.

Mardones, J. (2003). Filosofía de las ciencias humanas y sociales. Materiales para una fundamentación científica. Antropos.

Masuhara, H., Hann, M., Yi, Y., \& Tomlinson, B. (2008). Adult EFL courses, ELT Journal, 62 (3), 294-312. 
McDonough, J., Shaw, C., \& Masuhara, H. (2013). Materials and methods in ELT: A teacher's guide (3rd Ed.). John Wiley \& Sons.

Mignolo, W. (2010). Delinking: The rhetoric of modernity, the logic of coloniality and the grammar of de-coloniality. In W. Mignolo \& A. Escobar (Eds.), Globalization and the decolonial option (pp. 303-368). Routledge.

Mignolo, W. D. (2007). El pensamiento decolonial: Desprendimiento y apertura. Un manifiesto. In S. Castro-Gómez \& R. Grosfoguel (Eds), El giro decolonial: Reflexiones para una diversidad epistémica más allá del capitalismo global (pp. 25.46). Universidad Central, Instituto de Estudios Sociales Contemporáneos y Pontificia Universidad Javeriana, Instituto.

Ministerio de Educación Nacional [MEN] (2016). Suggested curriculum structure. Grades 6th to 11th. https://aprende.colombiaaprende.edu.co/sites/default/files/naspublic/Anexo\%2013\%20 Suggested $\% 20$ Structure.pdf

Ministerio de Educación Nacional de Colombia (MEN) (2014). Colombia Very Well Programa Nacional de Inglés 2015- 2025. https://www.mineducacion.gov.co/1759/articles-343837_Programa_Nacional_Ingles.pdf

Montijano, Del P. (2014). Textbook use training in EFL teacher education. Utrecht Studies in Language \& Communication, 27, 267-286.

Moran, P. (2001). Teaching culture: Perspectives in practice. Heinle \& Heinle.

Moreno, M., \& Pájaro, M. (2018). Indisciplining the curriculum from a complex perspective to teach English. English Language Teaching, 11(9), 26-32. http://doi.org/10.5539/elt.v11n9p26

Ndura, E. (2010). ESL and cultural bias: An analysis of elementary through high school textbooks in the western United States of America. Language, Culture and Curriculum, 17(2), 143-153.

Nguyen, C. T. (2015). An evaluation of the textbook. English 6: A case study from secondary schools in the Mekong Delta Provinces of Vietnam. (Unpublished Doctorate Thesis). University of Sheffield.

Nofall, M. \& Qawar, H. (2015). Gender representation in English language textbooks: Action pack 10. American Journal of Educational Science, 1(2), 14-18.

Núñez, A., \& Téllez, M. (2009). ELT materials: the key to fostering effective teaching and learning settings. Profile: Issues in Teachers' Professional Development, 11(2), 173-186.

Núñez, A., \& Téllez, M. F. (2015). Reflection on teachers' personal and professional growth through a materials development seminar. HOW Journal, 22(2), 57-74.

Núñez, A., \& Téllez, M. F. (2018). The argumentative competence through in-class debates on social issues. In A. Núñez, M. F. Téllez, \& J. Gómez (Eds.), Teacher-developed materials for language teaching and learning. (pp. 19-103). Departamento de Publicaciones Universidad Externado de Colombia.

Núñez, A., Téllez, M. F., \& Castellanos, J. (2013). Proposal for the research line materials development and didactics ascribed to the research group: Critical pedagogy and didactics for social transformation (Unpublished manuscript, School of Education). Universidad Externado de Colombia, Bogotá, Colombia.

Núñez-Pardo, A. (2018a). The English textbook. Tensions from an intercultural perspective. Gist, Education and Learning Resource Journal, (17), 230-259. 
Núñez-Pardo, A. (2018b). Critical interculturality to disrupt coloniality in the English textbook. Cuestiones Educativas, 1-9.

Núñez-Pardo, A. (2020a). A critical reflection on developing and implementing in-house EFL textbooks. Revista Papeles, 11(21), 11-31.

Núñez-Pardo, A. (2020b). Rethinking the EFL textbook from a critical interculturality stance. In J. A. Álvarez-Valencia, A. Ramírez-Espinosa, \& O. Vergara-Luján (Eds.), Interculturality in teacher education: Theoretical and practical considerations (pp. 248-304). Universidad del Valle (in print).

Núñez-Pardo, A., \& Téllez, M. F. (2020). Tracing the cultural component in teacher generated EFL materials. In A. Núñez-Pardo \& M. F. Téllez-Téllez (Eds.), Defying culture hegemony through teacher generated materials (pp. 19-103). Departamento de Publicaciones Universidad Externado de Colombia (in print).

Pennycook, A. (1994). The cultural politics of English as an international language. Routledge.

Pennycook, A. (1998). English and the discourses of colonialism. Routledge.

Pereira, A. (2013). Representações de gênero em livros didáticos de língua estrangeira: discursos gendrados e suas implicações para o ensino. In A. Pereira \& L. Gottheim, (Org.). Materiais didáticos para o ensino de língua estrangeira: processos de criação e contextos de uso. Mercado de Letras, 1, 113-146.

Pérez-Gómez, Á. (1998). La cultura escolar en la sociedad neoliberal. Morata.

Phillipson, R. (2012). Linguistic imperialism alive and kicking. Guardian Weekly.

Porreca, K. (1984). Sexism in current ESL textbooks. TESOL Quarterly, 18(4) 705-724.

Prabhu, N. S. (1987). Second language pedagogy. Oxford University Press.

Prabhu, N. S. (1990). There is no best method-Why? TESOL Quarterly, 24, 161-176.

Prodromou, L. (1988). English as cultural action. ELT Journal, 42(2), 73-83.

Pulverness, A. (2003). Materials for cultural awareness. In B. Tomlinson (Ed), Developing materials for language teaching (pp. 426-438). Continuum.

Quiceno, H. (1998). De la pedagogía como ciencia a la pedagogía como acontecimiento. Revista Educación y Pedagogía, 19/20, 140-158.

Quijano, A. (1980). Dominación y cultura. Lo cholo y el conflicto cultural en el Perú. Mosca Azul Editor.

Quijano, A. (2014). Cuestiones y horizontes: de la dependencia bistórico-estructural a la colonialidad/descolonialidad del poder. CLACSO.

Quijano, A., \& Wallerstein, I. (1992). La americanidad como concepto, o América en el moderno sistema mundial. RICS, 134, 583-591.

Restrepo, E., \& Rojas, A. (2010). Inflexión decolonial. Fuentes, conceptos y cuestionamientos. Universidad del Cauca, Instituto de Estudios Sociales y Culturales Pensar; Maestría en Estudios Culturales, Universidad Javeriana.

Rico, C. (2010). The effects on language materials on the development of intercultural competence. In B. Tomlinson \& H. Masuhara (Eds), Research for materials development in language learning evidence for best practice (pp. 84-201). Continuum. 
Rico, C. (2012). Language teaching materials as mediators for ICC development: A challenge for materials developers. Signo y Pensamiento, 30, 130- 154.

Rimani, F., \& Soleimani, F. (2012). The manifestation of culture in Iranian and Turkish high school English textbooks. Academic Research International, 2(3), 646-656.

Rossner, R. (1988). Materials for communicative language teaching and learning. Annual Review of Applied Linguistics 8, 140-63.

Sapir, E. (1949). Culture, language and personality: Selected essays. University of California Press.

Sercu, L. (2005). Opinions regarding different facets of intercultural competence teaching. In L. Sercu (Comp), Foreign language teachers and intercultural competence an international investigation (pp. 109-120). Multilingual Matters Ltd.

Shulman, L. (1987). Knowledge and teaching: Foundation of the new reform. Harvard Educational Review, 57(1), 1-23.

Syarifuddin, (2014). Sexism in EFL textbooks used in Indonesian schools. Lingua, 9(1), 62-74.

Tomlinson, B. (2012). State-of-the-art article materials development for language learning and teaching. Cambridge University Press.

Tomlinson, B. (2013). Developing materials for language teaching. Bloomsbury Publishing Plc.

Tomlinson, B. (Ed.) (1998). Materials development in language teaching. Cambridge University Press.

Tomlinson, B., \& Masuhara, H. (Eds.) (2010). Research for materials development in language learning: Evidence for best practice. Continuum.

Torres, C. A. (2010). Pensar la investigación desde el margen de las ciencias sociales. In ¿Cómo pensar las ciencias sociales hoy? Siglo del Hombre Editores.

Usma, J. (2009). Education and language policy in Colombia: Exploring processes of inclusion, exclusion, and stratification in times of global reform. Profile: Issues in Teachers' Professional Development, $11,123-141$.

Valencia, S. (2006). Literacy practices, texts, and talk around texts: English language teaching developments in Colombia. Colombian Applied Linguistics Journal, 8, 7-37.

Valtierra-Zamudio, J. (2012). Del discurso crítico a la práctica para una investigación situada. CLACSO.

Varón, M. E. (2009). Componente cultural, libros de texto y enseñanza del inglés como lengua extranjera. Forma y Función, 22(1), 95-124.

Vasco, C. (1990). Tres estilos de trabajo en las ciencias sociales. CINEP, Centro de Investigación y Educación Popular PREÁMBILO.

Viáfara, J. J. (2016). "I'm Missing Something": (Non) Nativeness in prospective teachers as Spanish and English speakers. Colombian Applied Linguistics Journal, 18(2), 11-24.

Walsh, C. (2005a). Interculturalidad, conocimientos y decolonialidad. Revista Signo y Pensamiento, 44(XXIV), 39-50.

Walsh, C. (2005b). La Interculturalidad en la educación. Ministerio de Educación -Dirección Nacional de Educación Bilingüe Intercultural. DINEBI. 
Walsh, C. (2009). Interculturalidad crítica y educación intercultural. Artículo ampliación de la ponencia presentada en el Seminario 'Interculturalidad y Educación Intercultural', organizado por el Instituto Internacional de Integración del Convenio Andrés Bello, La Paz, 9-11 de marzo de 2009. pp. 1-18.

Walsh, C. (2014). Lo pedagógico y lo decolonial: entretejiendo caminos. In C. Walsh (Ed.), Pedagogías Decoloniales. Prácticas Insurgentes de resistir, (re) existir y (re)vivir Tomo I (pp. 23 - 68). Editorial Abya Yala.

Walsh, C. (2015). ¿Interculturalidad? Fantasmas, fantasías y funcionalismos. In C. Montufar \& F. Balseca (Eds.), Ecuador: desafíos para el presente y el futuro (pp. 269-282). Universidad Andina Simón Bolívar, Ediciones La Tierra.

Wallerstein, I. (1974). The modern world system: Capitalist agriculture and the origins of the European world economy in the sixteenth century. New York, NY: Academic Press.

Waters, A. (2009). Advances in materials design. In M. Long \& C. J. Doughty (Eds.), The handbook of language teaching (pp. 373-394). Blackwell Publishing Ltd.

Whorf, B. (1956). Language, thought, and reality. Massachusetts Institute of Technology Press.

Widdowson, H. G. (1998). Context, community, and authentic language. TESOL Quarterly, 32(4), 70516.

Xiao, J. (2010). Cultural content of an in-use EFL textbook in English major students' attitudes and perceptions towards culture learning at Jiangxi University of Science and Technology (Doctorate Thesis). China: Prince of Songkla University.

Yassine, S. (2012). Culture issues, ideology and otherness in EFL textbooks: A social, semiotic, multimodal approach (Doctorate Thesis). Algeria, Africa: Mouloud Mammeri University of Tizi- Ouzou.

Zhang, X. (2017). A critical review of literature on English language teaching textbook evaluation: What systemic functional linguistics can offer. Journal of Language and Cultural Education, 5(1), 78-102.

Zuleta, E. (1990). Estudios Sobre la Psicosis. Percepción. 